the enormous problems posed by the accident and the serious long-term effects on both health and nuclear power. It is flawed by a lack of quantified interpretasure that Medvedev knows that the water cooling the condensers of a boiling water reactor does not pass through the core and that iodine isotopes do not decay by fistion and by many errors, some due to ignorance and some to carelessness. I am

\section{American pie}

\section{Tim Lincoln}

The Newtonian Casino. By Thomas A. Bass. Longman: 1990. Pp.329. £12.95*.

IN THE early years of their statehood, the economies of California and its neighbour Nevada rested on digging gold and silver out of the ground. In 1931, with the legalization of gambling, Nevada decided on the more straightforward strategy of digging them out of people's pockets as well, not least the pockets of Californians. The high life of casino owners in Las Vegas and in Reno, its smaller northern counterpart, was (and is) in part paid for by the losses at their tables of the citizens of Los Angeles and San Francisco.

Thomas Bass's book is an insider's account of how, during the late $1970 \mathrm{~s}$, a bunch of free-wheeling young physicists centred on the University of California at Santa Cruz attempted to recoup some of that money. Their dream was to build for themselves a world above workaday considerations; their way of realizing it, like that of many before them, was to beat the house at roulette. It is an extraordinary story that is believable only because, true to life, it rambles somewhat, and because the dénouement is one which no publisher of fiction would have tolerated.

Luck isn't much help in winning at roulette, except in the short term, nor are mathematical systems, which require a bank of infinite size and a casino that doesn't set an upper limit on bets. Instead the Santa Cruz group set itself the task of constructing a prediction system based on the laws of physics. If enough is known about the forces acting on the ball and rotor of a particular roulette wheel, the ball's final resting place can be estimated with enough certainty to give the gambler (with this system a gambler no more) a comfortable advantage over the house. The problem then, nontrivial as it turned out, was to write a computer program of sufficient sophistication to take account of all the variables; to build the hardware to run it; and to devise a method of communication in which the prediction could be transmitted from one person

4. Published four years ago in the United States by Houghton Mifflin under the title The Eudaemonic Pie. bets. There was also the small matter of staying cool in casinos, places not renowned for their love of winners, when wired up with roulette-beating electronic equipment.

Two things made the physicists' assault on Nevada different from the attempts of those who had gone before them. One was that greed was tempered not only by idealism but by a thoroughly businesslike attitude. A company was formed, Eudaemonic Enterprises, (eudaemia being the spirit of rationality), the company's object being to create a pie from the winnings in which everyone who had contributed to the project would share. The other was miniaturization of the equipment, made possible only by the advent of the microprocessor in 1970; Silicon Valley, of course, was on the doorstep.

That the entire system ended up being fitted into three shoes - two worn by the data-taker, the other by the person laying the bets - was a triumph of perseverance and ingenuity. That their work on the taking the data to another placing the sion, but he has allowed these absurdities to remain in the text. I can recommend the book to those who want a general account of Chernobyl and its aftermath and who are not too worried about the accuracy of detail, but I cannot recommend it as an authoritative source of information.

John Dunster, 108 Defoe House, Barbican, London EC2Y $8 D N$, UK, is a consultant on radiation protection.

project gave some of those involved a head start in the study of the new science of chaos, and ultimately academic respectability, was serendipitous.

Bass's chronicle is one of breakthrough and snafu. He is strong on the technical details, reticent about disagreements (surely there were more than he mentions). But they must have been heady years, the slog of putting together a working system and the frustrations of getting it to operate in casinos being punctuated most notably by crazy Halloween parties.

Behind the fun and games there lies an economic parable of the decade just passed. Half-way through the book, Wozniak and Jobs, the founders of Apple computers, make a fleeting appearance as the exemplars of dope-smoking, longhaired technological genius. At that point, one of the cast remarks: "As Xerox and IBM move in to package everything, I wonder if there's still going to be room for the hackers. That's where this country is still way ahead of the Japanese [who] don't have any place. . . for misfit hackers. But these are the people coming up with the truly creative ideas." When, ten years ago, Americans elected Ronald Reagan president, they announced that conservatism - short hair and much else besides - was back in fashion. Misfits aren't often found in a Brooks Brothers' suit. That might have been the day when, for innovation in the United States, the music started to die.

Tim Lincoln is News and Views editor of Nature.

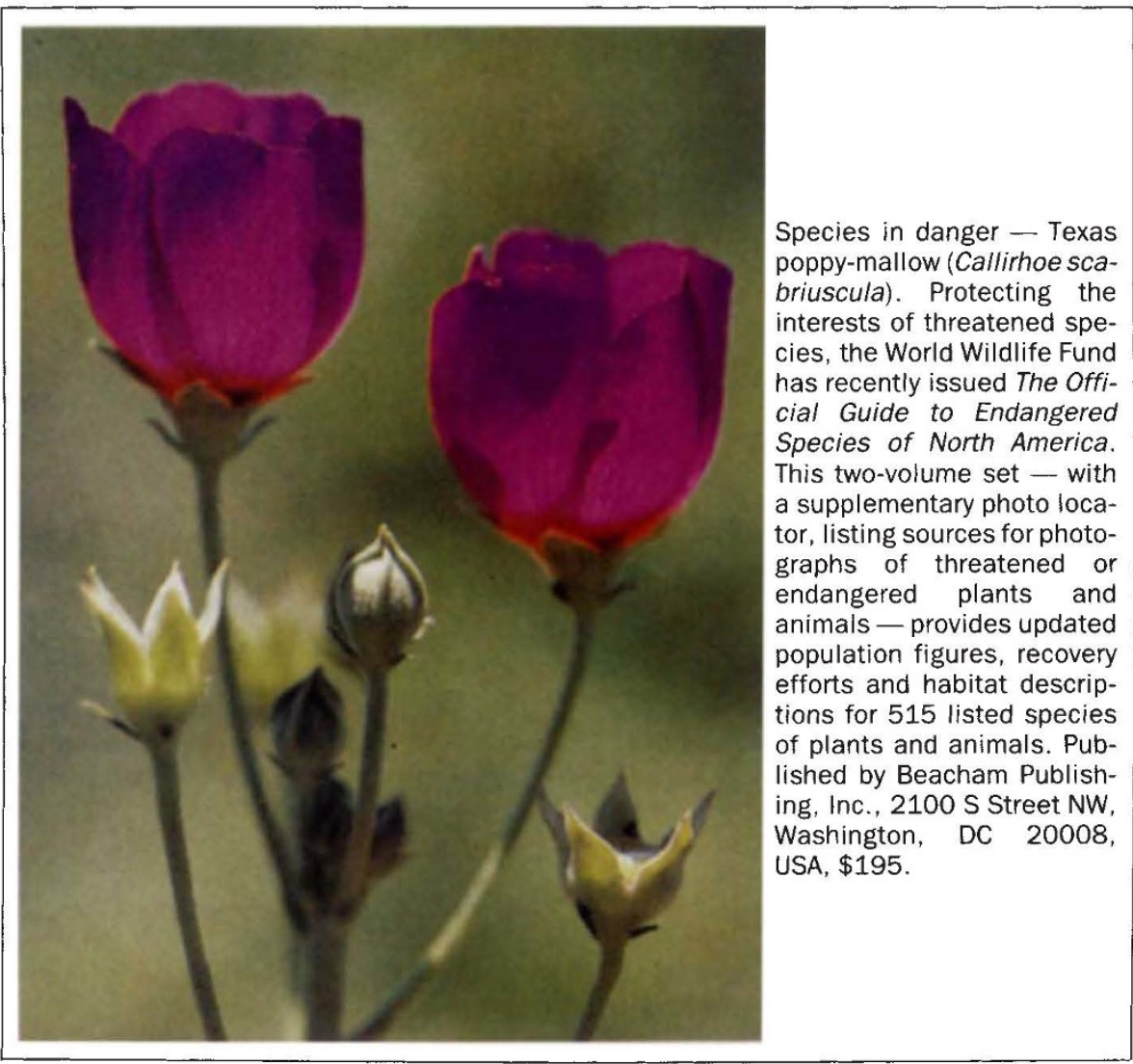

